\title{
Necessidade da Reorganização Rural do Brasil (*)
}

\author{
BYRON TORRES DE FREITAS
}

\begin{abstract}
Necessidade urgente da reorganização rural do Brasil, com a extinção gradual das grandes glebas improdutivas, mediante indenização, a curto ou longo prazo.

Ao mesmo tempo, incentivo concreto à produção agrícola, considerando-se que a simples entrega de terras aos lavradores pobres não soluciona a tremenda crise de abastecimento em que se debate o país.
\end{abstract}

Os órgãos que compõem a sociedade podem ser classificados em grupos. HERBERT SPENCER apresentou uma classificação da organização social em três grupos:

1. $\left.^{\circ}\right)$ o sistema sustentante;

2..$^{\circ}$ o sistema distributivo (sistema de transporte);

3..$^{\circ}$ o sistema regulador.

Gillin e BlaCKMAr completaram assim a classificação de SPEnCER:

$1^{\circ}$ ) os órgãos sustentadores (produção, transformação, transporte, trocas, etc. );

2..$^{\circ}$ os grupos perpetuadores (família, sociedades médicas e sanitárias);

$3^{\circ}$ ) os sistemas de comunicação (imprensa, telégrafo, rádio, telefone, vias férreas, veículos e motores, etc.);

4. ${ }^{\circ}$ ) os grupos culturais (igrejas, institutos educacionais, scciedades científicas, sociedades literárias e estéticas, clubes e sociedades mundanas e recreativas, etc. );

$5^{\circ}$ ) o sistema regulador e protetor (instituições internacionais, o Estado, as associações voluntárias, tais como organizações de trabalho, companhias de segurc, instituições de caridade, partidos políticos, etc.) (1)

Entre os fatôres secundários da organização social, notamos a influência recíproca da sociedade e de suas unidades. "Logo que uma combinação social toma alguma fixidez começa a provocar ações e reações entre a sociedade em sua totalidade e cada um de seus membrcs, de sorte que cada membro afeta a natureza do outro. A influência do agregado sôbre suas unidades tende sem

(*) Teзe apresentada ao IV Congresso Nacional de Municípios.

(1) OsBorn e NEUMEYER, $A$ comunidade e a sociedade, tradução brasileira. 
cessar a afeiçoar sua maneira de agir, seus sentimentos e suas idéias, conforme as necessidades sociais; enfim, tais maneiras de agir, de sentir e de pensar, na medida em que são modificadas pela mudança das circunstâncias, tendem a afeiçoar de novo a sociedade à sua semelhança.

Há no Brasil um visível desajustamento entre os vários grupos sociais, e iss') graças às condições medievais do meio rural. Um desanimador anacronisino domina a estrutura nacional - o latifúndio como unidade econômico-social a entravar o desenvolvimento da indústria. Duas épocas históricas coexistindo na mesma área geográfica.

Observa, ccm perfeita visão do prcblema, um escritor patrício: "Verificase assim que o latifúndio é o grande obstáculo à vida de relação entre as populaçõcs brasileiras. $O$ isolamento de sua existência reflete-se perniciosamente tanto no plano elevado das aspirações sociais, como no terreno fundamental das trocas comerciais. Econômicamente, é um empecilho formidável, reduzindo o consumo, não concorrendo para c barateamento da produção com o aumento de mercados. Socialmente", é um recinto fechado, segregado às correntes ideológicas e um retardador do progresso intelectual. Em tcdos os aspectos impede a circulação dos produtos ou idéias, aparecendo como entrave ao engrandecimento do país. E, raras vêzes, como nas fazendas cafeeiras paulistas ou nas estâncias pastoris gaúchas, é um centro de vida ativa, produtor de riqueza e manancial de regular fortuna. Sob outro aspecto, o latifúndio ainda perturba a economia nacional: é como o disseminador de nossas populações. As grandes extensões de terra em mãos de um único proprietário impedem o crescimento da densidade demográfica em cada quilômetro quadrado. As divisas de cada grande fazenda estorvam o estabelecimento de novas famílias naqueles campos incultos. E diante de infindáveis léguas de terrenos inaproveitáveis, os novos braços têm de bater em retirada, cada vez mais para dentrc do país. E que o latifúndio espalhou uma rêde extensíssima sôbre o território nacional, retalhando as sesmarias imensas, mas só pouco a pouco consente no estreitamento dessas malhas, na condensação de núcleos fortes e resistentes. Muito lentamente, como onda demográfica vai penetrando cs sertões, fugindo dos acotovelamentos do litoral. E as novas gerações e os recém-chegados vêem-se obrigados a procurar sítios distantes, longínquas terras devolutas. Ora, isso criou o nosso insolúvel problema das distâncias que tanto atormenta a administração pública. E o resultado são as nossas estradas de ferro deficitárias, cortando desertos para atingir um ou outro centro urbano mais importante, necessitando da vida de relação. (3) É que o latifúndio "já cumpriu inteiramente a sua missão histórica", devendo, por conseguinte, desâparecer.

Desaparecer, como? O mesmo autor propõe uma reforma agrária tendente a liquidar o feudalismo no Brasil. O govêrno desaprcpriaria, mediante in-

(2) Herbert Spencer, Principes de Sociologie, tradução francesa.

(3) Virgínio SAnta Rosa, o Sentido do Tenentismo, Rio 1933.- Convém notar que SANTA RoSA, resse caso dá marcha para o sertão, enuncia apenas um fenômeno regional, esquecendo-se da outra face da questão, isto é, o êxodo dos campos para as cidades. Leiase, sôbie o assunto, mestre Oliveira Viana, em Evolução do Povo Brasileiro e Populações Meridionais do Brasil. 
denização, os latifúndios que julgasse conveniente aos interêsses gerais, promoveria o estabelecimento de núcleos coloniais agrícolas nas proximidades dos centros urbanos do interior; apressaria a disseminação de pequenas propriedades ao redor das cidades mais importantes do nosso "hinterland".

O profundo desajustamento reinante entre os vários grupos sociais do Brasil impede que êles desempenhem as suas funções cooperativas, características de uma organização nacional equilibrada.

Seria, entretanto, incperante uma reforma agrária que consistisse apenas na entrega das terras aos lavradores pobres. Ao Estado cabe, "por meio de medidas que vão desde o saneamento das zonas produtoras até a garantia de mercado direto para os produtores". E, conforme aconselha o Sr. ERNANI do AMARal PEIXoto, financiar os agricultores e cooperativados; "isentá-los de impostos, facilitar-lhes créditos e, mediante êsses créditos, pôr a seu alcance as máquinas que substituam as ferramentas defeituosas e cibsoletas com que trabalham o solo, as sementes, amparo nas safras infelizes, etc. E, continua o Almirante Amaral Peixoto - cuidar da construção de estradas, silos, entrepostos - cobrindo o interior com uma rêde de transportes e armazenamento que racionalizem a distribuição dos produtos e promovam o barateamento nos centros de consumo".

Verifica-se, pois, a necessidade urgente da reorganização rural com a extensão gradual das grandes glebas improdutivas, mediante indenização a curto ou longo prazo.

Ao mesmo tempo, reorganização e incentivo concreto à produção agrícola, considerando-se que a simples entrega das terras os lavradores pobres não soluciona a tremenda crise de abastecimento em que o país se debate.

\section{CONCLUSÕES}

Não basta, entretanto, criticar, apontar erros e omissões. Assim, demonstrađa a urgência de ser expedida e executada uma "Lei de Recrganização Rural" no Brasil, propomos uma solução prática baseada no sucesso, em nosso país, da experiência das sociedades de economia mista, isto é, da cooperação financeira do Govêrno ccm o capital privado.

A solução seria o estabelecimento de uma sociedade de economia mista, denominada, por exemplo, Agrobrás S.A., que poderia ser instituída nas seguintes bases:

- autorização do Poder Legislativo ac Poder Executivo para constituir uma sociedade por ações sob a denominação de Agrobrás S.A., adotando-se para o efeito os dispositivos da Lei n. ${ }^{\circ} 3.115$, de 16-3-57;

- a Agrobrás S.A. terá objetivo de promover o aproveitamento e a exploração agropecuária de áreas de terra, preferencialmente devolutas;

- será utilizado, de preferência, o elemento nacional, na colonização dos núcleos agrícolas quo forem criados pela Agrobrás S.A.;

- será proporcicnada assistência financeira e técnica ao colono, no primeiro ano de sua instalação, ou, quando se torne indispensável; ocupar;

- serão previstas as condições de aquisição, pelo colono, da área que 
- a administração da Agrobrás S.A. poderá ifrmar convênio e acôrdos de cooperação com os governos estaduais e municipais, no sentido do cumprimento das suas finalidades;

- quando o interêsse da produção agrícola $\propto$ aconselhar, o govêrno poderá desapropriar latifúndios mediante indenização a longo prazo;

- Poder Executivo baixará decreto regulando o modo de administração e o funcicnamento da Agrobrás S.A., cujos dirigentes serão brasileiros natos;

- a Agrobrás S.A. terá a cooperação e a assistência técnica do Instituto Nacional de Imigração e Colonização do Serviço Social Rural, do Serviço do Patrimônic da União, além de entidades de direito privado.

Eis, pois, as conclusões a que chegamos, após uma análise perfunctória da situação agrária no Brasil.

NOTA - Parecer da Comissão Técnica, aprovado pelo Plenário:

"A Comissão recomenda o encaminhamento ao Govêrno Federal, por intermédio da Associação Brasileira de Municípios, das conclusões da Tese que independam da criação da "Agrobrás", nos moldes propostos a título de contribuição à política de seorganızação rural". 